\title{
A Química da Origem da Vida *
}

A possibilidade de realização de experiências laboratoriais simples para estudar a origem da vida foi referida pela primeira vez por Stanley Miller em 1953. Miller, um aluno do primeiro ano da Universidade de Chicago, convenceu Harold Urey que ambos deviam realizar experiências para pôr à prova a ideia de Urey de que a vida tinha tido a sua origem numa atmosfera redutora na Terra primitiva.

Fazendo passar uma descarga eléctrica através de uma mistura de metano, amoníaco, hidrogénio e vapor de água Miller obteve, com êxito, aminoácidos. Desde essa altura, foi demonstrada por um grande número de experiências a formação de aminoácidos e outros compostos orgânicos por sujeição de atmosferas terrestres primitivas a um certo número de diferentes fontes de energia.

Está-se actualmente num ponto de viragem no que respeita ao estudo laboratorial da origem da vida. Até agora, tem-se investigado detalhadamente a síntese de aminoácidos e outros monómeros simples essenciais à vida. A investigação actual centra-se mais na questão da formação de polímeros. Os estudos sobre a sintese pré-biótica de polímeros biológicos são agora mais fáceis, não só por causa da grande quantidade de dados laboratoriais obtidos nos últimos trinta anos, mas também pelo progresso feito noutras áreas científicas.

Por exemplo, como consequência da exploração do sistema solar, existe agora um melhor conhecimento sobre as condições prováveis em que a vida teve a sua origem. A partir de estudos de microrganismos fossilizados e de rochas antigas tem-se definido com maior precisão a escala de tempo para a evolução química $\mathrm{e}$ para a origem da vida. Teorias matemáticas propostas para a formação e evolução de espécies poliméricas podem agora ser avaliadas como consequência do desenvolvimento das capacidades de computação. O tipo de experiências adequado ao estudo da evolução química quando esta estava na sua infância está a ser substituído por experiências que se destinam a responder de uma maneira mais precisa a questões específicas referentes aos acontecimentos químicos que conduziram à origem da vida.

É importante, em primeiro lugar, definir o que se entende por "vida", para que seja possível distinguir as características essenciais de um sistema vivo das de outros conjuntos de moléculas. Parece-me que o critério proposto por Norman Horowitz do Instituto de Tecnologia da Califórnia é o mais útil: a vida possui propriedades de replicação, catálise e mutabilidade. Considero

\footnotetext{
" "The Chemistry of Life's Origin", James P. Ferris, Chemical \& Engineering News 62, pag. 22-35 (1984), tradução de A. Pinho de Aguiar, com autorização da American Chemical Soviety Copyright (1984).
}

como vivo qualquer sistema químico que possua estas três propriedades.

O problema central da origem da vida é saber-se como é que estruturas com propriedades de replicação, catálise e mutação se formaram na Terra. Isto é basicamente um problema químico, que pode ser subdividido em três fases: a síntese de monómeros, tais como aminoácidos e nucleótidos, a partir de hidrocarbonetos, ácido cianídrico, cianetos, aldeídos e acetonas; a polimerização destes monómeros em condições reaccionais semelhantes às que devem ter existido na Terra primitiva; e a formação espontânea de um sistema que sofra replicação e translação e que armazene informação. $\mathrm{O}$ estudo de rochas antigas e de microfósseis sugere quais as condições reaccionais que é provável terem predominado na Terra primitiva e por quanto tempo terá ocorrido a evolução química até ao aparecimento da vida. Deve-se salientar que, apesar dos enormes avanços que se têm verificado na compreensão dos fenómenos químicos e físicos que ocorreram nos primeiros tempos da existência da Terra, não há qualquer evidência experimental clara que sugira que um determinado cenário para as origens da vida seja o verdadeiro. Seleccionei para apreciação aquelas teorias que me parecem ser mais consistentes com os dados experimentais actualmente disponiveis.

A química da Terra primitiva foi determinada pelos elementos de que era formada. Por essa razão, uma compreensão do modo como se formou o sistema solar (com ênfase para a Terra) é um primeiro passo importante para a compreensão da origem da vida.

O Sol e os planetas do nosso sistema solar formaram-se há cerca de quatro biliões e meio de anos, enquanto que as primeiras estrelas, no centro da nossa galáxia, tiveram a sua origem há dez biliões de anos. A condensação de uma núvem de gás e poeira interestelar para formar o sistema solar talvez tenha sido provocada pela explosão de uma estrela vizinha como uma supernova. Esta núvem de poeira e gás transformou-se num disco de poeira e moléculas a partir do qual se formaram o Sol e os planetas.

Os planetas interiores - Mercúrio, Vénus, Terra e Marte - contêm uma percentagem muito maior dos elementos mais pesados do que os quatro grandes planetas situados para além de Marte. As temperaturas mais elevadas na vizinhança do Sol impediram a condensação dos elementos do $1 .^{\circ}$ periodo da Tabela Periódica, mais leves. Temperaturas abaixo de $150 \mathrm{~K}$ na órbita de Júpiter causaram a condensação da água. Quando Júpiter, Saturno, Urano e Neptuno se formaram, a massa de material acumulado foi suficientemen-

\footnotetext{
Instituto Politécnico Rensselaer.
} 
te grande para atrair e manter junto a si, juntamente com os elementos mais densos, o hidrogénio e o hélio. Quando se formou a Terra, ela era constituida principalmente pelos elementos mais pesados. No entanto, no seu percurso orbital em torno do Sol, agregou a si largas quantidades de poeiras e planetesimais (objectos sólidos muito mais pequenos do que os planetas), ambos contendo uma grande proporção de elementos mais leves. A existência de um grande número de crateras que se observam na Lua, Mercúrio e em muitos dos satélites de Júpiter e de Saturno apontam no sentido da Terra ter sido também submetida, em tempos primitivos a um intenso bombardeamento. Este processo de crescimento preparou o meio para a evolução química, dado que este revestimento de material menos denso estava enriquecido nos elementos mais leves a partir dos quais a vida teve a sua origem.

A investigação por espectroscopia das espécies moleculares presentes em núvens de poeira na nossa galáxia fornece uma boa pista para o conhecimento dos compostos presentes na poeira e nos gases a partir dos quais se formou o nosso sistema solar. Foi detectada uma grande abundância de compostos de carbono e azoto, incluindo metano, formaldeído, ácido fórmico, amoníaco e ácido cianidrico. Os químicos que têm estudado a síntese de compostos orgânicos na Terra primitiva obtiveram uma grande satisfação com estas descobertas radioastronómicas, uma vez que tinham previamente sugerido que muitos destes compostos eram matérias-primas plausiveis para as origens da vida.

A presença destas moléculas no meio interestelar (um conjunto muito mais limitado existe na atmosfera de Titã, a maior lua de Saturno) leva a supor que provavelmente estariam também presentes na Terra primitiva. Estes compostos de carbono e azoto podem não ter sido transferidos intactos da núvem de poeira para a atmosfera da Terra primitiva, mas a facilidade com que se formam noutros ambientes apoia o ponto de vista de que se formaram na Terra e de que estavam presentes na sua atmosfera e hidrosfera.

Alguns dos planetesinais menos densos absorvidos pela Terra primitiva foram cometas e corpos semelhantes a cometas. Os cometas que hoje se observam podem eventualmente conter vestígios da núvem de poeira primordial. Os cometas existem nas regiões exteriores e frias do sistema solar para lá de Plutão e têm sofrido modificações químicas relativamente pequenas nesse meio frigido. Algumas moléculas detectadas no espaço interestelar foram também detectadas em cometas, observação essa que está de acordo com a hipótese de que os cometas se formaram por condensação de compostos na núvem de poeira primordial.

Uma sonda directa do meio interestelar são os meteoritos que atingem a Terra. Os meteoritos carbonosos, que contêm até $5 \%$ de carbono, são de especial interesse no campo da evolução química. O tratamento destes meteoritos com água e ácido diluído conduz à obtenção de, entre outros compostos, purinas, pirimidinas e aminoácidos. É provável que meteoritos semelhantes tenham colidido com a Terra há 4,0 a 4,5 biliões de anos. Os meteoritos carbonosos têm teores de carbono, hidrogénio e azoto inferiores aos do Sol, o que sugere terem eles tido a sua origem em planetesimais, que nunca tiveram massa suficientemente elevada para acumularem os elementos do $1 .^{\circ}$ periodo da Tabela Periódica, menos densos.

Os meteoritos carbonosos são uma fonte de informação que faz levantar muitas dúvidas no que diz respei- to aos processos químicos que tiveram lugar na Terra primitiva. Infelizmente, a falta de dados sobre a sua origem, formação e abundância torna dificil a interpretação desta informação.

Foram sugeridos três cenários para o seu papel na origem da vida. O mais simples assume que os meteoritos carbonosos trouxeram para a Terra quantidades significativas de compostos de carbono pré-formados no período de bombardeamento meteorítico intenso. O processo da evolução química teria sido com certeza facilitado por uma tal injecção de moléculas orgânicas pré-formadas.

Um segundo cenário é semelhante, com a excepção de que postula que esses compostos orgânicos sofreram pirólise ao serem adicionados à superficie da Terra ou pouco tempo depois, devido ao seu transporte para regiōes quentes existentes sob a crosta terrestre. Os compostos orgânicos pré-formados teriam sido destruidos, mas o processo de pirólise teria libertado gases orgânicos reduzidos que teriam servido como ponto de partida para a evolução química.

Uma terceira possibilidade é que os meteoritos carbonosos não tenham trazido quantidades significativas de material orgânico para a Terra primitiva, uma vez que hoje em dia eles constituem apenas cerca de $2 \%$ dos meteoritos que alcançam a Terra. Mesmo que isso seja verdade, as moléculas biológicas e outros compostos orgânicos reduzidos observados nesses meteoritos devem ter sido formados no sistema solar por processos químicos semelhantes àqueles que foram postulados para a origem da vida na Terra. Esta interpretação serve de suporte às premissas básicas da investigação sobre as origens da vida, mas requer fontes alternativas para os compostos orgânicos reduzidos que servem de matérias-primas.

\section{Atmosferas planetárias}

A composição e a química da atmosfera da Terra há 4 biliões de anos podem ser inferidas em parte a partir do conhecimento adquirido com as sondas que a NASA (Administração Nacional para a Aeronáutica e Espaço) enviou a outros planetas. Descobriu-se que o anidrido carbónico era um constituinte principal das atmosferas de Vénus e Marte, planetas que ladeiam a Terra. Consequentemente, parece provável que o anidrido carbónico tenha sido um constituinte atmosférico principal da Terra primitiva.

Poder-se-ia argumentar que Marte e Vénus tinham atmosferas redutoras no início, atmosferas essas que gradualmente se tornaram oxidantes ao longo dos últimos 4 biliōes de anos como consequência da fotólise da água, que teria originado radicais hidroxilo e oxigénio molecular. No entanto, a proposta da existência de abundância de anidrido carbónico na Terra é apoiada pelos grandes depósitos de calcário existentes na Terra, pela presença de carbonatos sedimentares em formações rochosas de 3,8 biliões de anos de idade e pelo facto do anidrido carbónico ser um dos gases principais emitidos hoje em dia pelos vulcões. Esta conclusão é consideravelmente diferente da atmosfera de metano-amoníaco-água postulada por Urey a partir de considerações termodinâmicas. Ela não elimina a presença de quantidades mais pequenas de compostos de carbono reduzidos, a partir dos quais se formaram as biomoléculas essenciais para as origens da vida.

Os quatro grandes planetas ricos em hidrogénio não são um bom modelo para a Terra primitiva, uma vez 
que não temos nenhuma razão para acreditar que o hidrogénio tenha sido mais do que um componente minoritário da atmosfera terrestre. A missão Voyager 1 sugeriu de facto que alguns aspectos da química atmosférica de Titã podem reflectir, melhor do que em qualquer outro corpo do sistema solar actual, os acontecimentos químicos que tiveram lugar na Terra primitiva. Rudolph A. Hanel e colaboradores seus no Centro de Voo Espacial Goddard da NASA detectaram a existência de ácido cianídrico, cianogénio, cianoacetileno, acetileno, diacetileno, metilacetileno, etileno e etano em Titã, por espectroscopia de emissão no infravermelho. Estes compostos estão provavelmente a ser formados pela acção de electrões de elevada energia, de raios cósmicos (protões de elevada energia) e de luz ultravioleta na atmosfera de metano-azoto de Titã.

A bruma alaranjada que obscurece a superfície de Titã é provavelmente devida a núvens de hidrocarbonetos e cianocarbonetos. Os oceanos de hidrocarbonetos existentes em Titã poderão conter grandes quantidades de hidrocarbonetos e cianocarbonetos de elevada massa molecular que se formaram na atmosfera superior e depois se condensaram na superficie fria $(94 \mathrm{~K})$ do planeta durante os últimos 4,5 biliōes de anos. Estes compostos estão provavelmente a reagir muito devagar ou praticamente nada na superfície de Titã, não só porque a temperatura é muito baixa, mas também porque estão protegidos de fontes de energia externas pela atmosfera enevoada.

No entanto, a grande semelhança entre a composição da mistura de compostos encontrada no espaço interestelar, em cometas e em Titã sugere fortemente que estes mesmos compostos se formaram na atmosfera da Terra primitiva. As suas reacções posteriores no meio quente e aquoso existente na Terra seriam obviamente bastante diferentes das que tiveram lugar na lama frígida de hidrocarbonetos de Titã.

Pode-se fazer a objecção de que se o anidrido carbónico fosse o componente principal da atmosfera da Terra primitiva, era pouco provável que compostos com o nivel de oxidação do ácido cianídrico e do cianoacetileno tivessem lá estado presentes. Por exemplo, quando o anidrido carbónico é usado como matéria-prima em experiências de simulação da Terra primitiva só se obtém, no máximo, vestígios de formaldeido. É intrinsecamente dificil reduzir anidrido carbónico com água e azoto.

No entanto, há várias maneiras de ultrapassar esta dificuldade. Quantidades mais pequenas das formas mais reduzidas de carbono, como o monóxido de carbono, formaldeido e metano, podem ter sido trazidas para a Terra através de cometas e meteoritos. Outra possibilidade é a de estes compostos reduzidos, juntamente com hidrogénio, terem sido expelidos por vulcões, sob a forma de gases, na era pré-biótica, como resultado da redução de anidrido carbónico com ferro (II) (ferroso). De facto, reacções de redução do mesmo tipo têm lugar hoje em dia no fundo do mar em centros activos situados no meio dos oceanos, onde uma combinação de elevadas temperaturas e ferro (II) conduz à conversão de sulfato em sulfureto. Nestas aberturas existentes no fundo dos mares, a pirólise de compostos orgânicos derivados de materiais biológicos existentes em sedimentos dá origem a metano, amoníaco e hidrogénio. Uma outra hipótese proposta é que o metano emitido por essas aberturas seja produzido por bactérias anaeróbias. Com efeito foi relatado que microrganismos produtores de metano, existentes em amostras tiradas dessas aberturas, são capazes de crescimento à temperatura de $250^{\circ} \mathrm{C}$ e à pressão de 265 atm. Esta descoberta controversa, se fôr confirmada, indicará que a bioquímica dos processos da vida pode dar-se em condições muito para além do que até agora se imaginava ser possível.

\section{A vida mais antiga na Terra}

Os estudos feitos sobre a Galáxia e a exploração do sistema solar dão-nos uma razoável ideia dos reagentes e das condições reaccionais existentes na Terra primitiva. $\mathrm{O}$ que falta determinar é durante quanto tempo se deram as reacções até surgir pela primeira vez a vida. Pode-se obter um limite superior para o tempo de reacção a partir da prova da existência da vida mais antiga na Terra.

A primeira prova definitiva da existência da vida pré-câmbrica (de há 600 milhōes a 4,5 biliōes de anos) foi relatada em 1954 pelos falecidos Stanley A. Tyler do Departamento de Geologia da Universidade de Wisconsin e Elso S. Barghoorn do Departamento de Biologia da Universidade de Harvard, que descreveram um certo número de bactérias de diferentes tipos existentes na formação rochosa Gunflint perto do lago Superior do Canadá e que têm 2 biliões de anos. Estas formas de vida simples estavam embutidas e preservadas em sedimentos que se transformaram mais tarde em rochas. Em 1980, um grupo internacional de 24 cientistas organizado pelo paleobiólogo J. William Schopf e a trabaIhar na Universidade da Califórnia, Los Angeles, apresentou provas da existência de vida microbiana na Terra há 3,5 biliōes de anos recorrendo a fósseis. Schopf formou este grupo para efectuar um estudo interdisciplinar concentrado das mais antigas rochas da Terra, incluindo um estromatólito antigo, um recife de microrganismos primitivos, proveniente da Austrália Ocidental.

Os estromatólitos são estruturas com a forma de cúpula que crescem em bacias de marés. Formam-se como resultado da aderência de areia, calcário e outros pedaços de rocha ao revestimento viscoso de certos microrganismos bacterianos. Cada ano cresce uma nova camada de microrganismos em cima da areia e dos fragmentos. Através do uso de técnicas radioactivas de datação chegou-se à conclusão que os minerais presentes no estromatólito da Austrália Ocidental - que é morfologicamente semelhante aos estromatólitos contemporâneos da Baía do Tubarão, Austrália - tinham 3,5 biliões de anos de idade. Uma vez que se pensa que a idade da Terra é de cerca de 4,5 biliões de anos, conclui-se que o processo que deu origem à vida durou menos de 1 bilião de anos, embora não se saiba se muito menos se pouco menos do que isso.

Embora o nosso conhecimento sobre os processos químicos que se verificaram na Terra primitiva tenha aumentado consideravelmente, as condições reaccionais que conduziram às origens da vida não são ainda conhecidas em definitivo. É possível criar cenários bastante diferentes dentro dos limites dos conhecimentos actuais. A maior parte das experiências laboratoriais são planeadas para examinar um determinado cenário construído a partir de suposições àcerca da Terra primitiva. As experiências só têm significado se fôr possível mostrar a validade dessas suposições.

As hipóteses gerais que se apresentam a seguir estão implícitas na maior parte das discussões sobre a evolução química: 
- A vida na Terra teve a sua origem na Terra. Os cenários baseados na sua origem noutros locais são praticamente impossiveis de verificar.

- A bioquímica da vida inicial era semelhante à bioquímica contemporânea, embora muito mais simples; é, no entanto, possível especular acerca da existência de sistemas vivos em que o carbono, por exemplo, seja substituido por silício e/ou a água substituida por amoníaco.

- Os processos químicos que conduziram às origens da vida ocorreram na presença de água e de minerais, com valores de $\mathrm{pH}$ da fase aquosa compreendidos entre 6 e 9, embora possam ter existido variações locais. $\mathrm{O}$ anidrido carbónico e a água eram os constituintes principais da atmosfera, atmosfera essa que não continha mais do que vestígios de oxigénio molecular. Existiam também na atmosfera baixas pressões parciais de monóxido de carbono, metano e hidrogénio, existindo pequenas quantidades de amoníaco, ácido cianídrico e ácido sulfídrico dissolvidos nos lagos e oceanos primitivos. Podem ter existido concentraçōes localizadas mais elevadas de alguns destes compostos devido à sua formação nesses locais ou na sua proximidade.

- Os processos químicos que conduziram às origens da vida foram desencadeados principalmente por intermédio da energia solar. Esta pode ter actuado sob a forma directa de luz visível e ultravioleta, ou indirectamente sob a forma de relâmpagos (descargas eléctricas e suas ondas de choque) ou de energia térmica. A adicionar ao calor do sol, alguma energia térmica terá sido fornecida por acções tectónicas (vulcões e fendas da crosta), impacto de meteoritos e decaímento radioactivo.

Examinemos em primeiro lugar experiências destinadas a imitar a formação pré-biótica de aminoácidos, os blocos de construção cruciais para a vida, tais como as primeiras realizadas por Miller que serviram para demonstrar de uma forma dramática que as origens da vida podem ser estudadas no laboratório. Miller fez passar durante uma semana uma descarga eléctrica através da sua mistura de metano, amoníaco, hidrogénio e vapor de água com o objectivo de produzir aminoácidos. Foram também obtidos hidroxiácidos, aldeídos e ácido cianidrico em quantidades comparáveis às dos aminoácidos, o que indica que a maior parte dos aminoácidos era formada pela adição de amoníaco e ácido cianídrico a aldeidos para formar $\alpha$-aminonitrilos, compostos estes que sofriam hidrólise originando os correspondentes aminoácidos.

$$
\mathrm{RCHO}+\mathrm{HCN}+\mathrm{NH}_{3} \rightarrow \underset{\mathrm{NH}_{2}}{\mathrm{RC}} \underset{\mathrm{HCN}_{2}}{\rightarrow} \underset{\mathrm{NH}_{2}}{\mathrm{RCHCO}}
$$$$
\alpha \text {-aminonitrilos aminoácidos }
$$

Quando a fonte de carbono é o metano formam-se desta maneira cerca de metade dos 20 aminoácidos primários. Em estudos subsequentes realizados na Universidade da Califórnia, San Diego, Miller descobriu que se forma metionina quando se adiciona ácido sulfídrico e que se produzem alguns aminoácidos aromáticos quando os hidrocarbonetos aromáticos formados por pirólise do metano se combinam com os produtos da reacção que se dá com a descarga eléctrica.

Libertam-se também aminoácidos por hidrólise de oligómeros formados por auto-condensação de ácido cia- nídrico em solução aquosa. O ácido cianídrico é uma matéria-prima pré-biótica provável, uma vez que é produzido em quantidades apreciáveis pela acção de descargas eléctricas e ondas de choque em atmosferas primitivas simuladas. Nos produtos de hidrólise de um oligómero do $\mathrm{HCN}$ foram identificados glicina, alanina e ácido aspártico, juntamente com cinco aminoácidos que se não encontram em proteínas.

Foram também produzidos aminoácidos com baixo rendimento por acção do calor $\left(900^{\circ} \mathrm{C}\right)$, raios gama, ondas de choque e luz ultravioleta de baixo comprimento de onda em modelos de atmosferas primitivas. Estas descobertas sugerem que, na Terra primitiva, os aminoácidos foram produzidos por um certo número de vias diferentes. Como já se referiu, os aminoácidos podem também ter sido trazidos para a Terra por meteoritos carbonosos. Não se sabe ainda quais foram as fontes mais importantes.

\section{Componentes dos ácidos nucleicos.}

Os nucleótidos são outros blocos básicos para a construção da vida. Os ácidos nucleicos são geralmente considerados como tendo sido os portadores da informação genética nos sistemas vivos mais antigos, embora os processos genéticos possam ter sido menos precisos do que são hoje em dia. Consequentemente, a sintese de ácidos nucleicos a partir de nucleótidos precedeu provavelmente o aparecimento da vida.

Além de serem constituintes dos ácidos nucleicos, as purinas são também componentes importantes de muitos coenzimas. Um dos compostos heterocíclicos mais abundantes de entre os existentes nas estruturas bioquimicas é a adenina. É também o mais fácil de sintetizar em experiências de simulação da Terra primitiva. A sintese directa da adenina a partir de soluções concentradas de ácido cianídrico foi levada a cabo em 1960 por John Oro da Universidade de Houston. Em 1963, Melvin Calvin e os seus colaboradores na Universidade da Califórnia, Berkeley, relataram a formação de adenina quando se irradiava uma mistura de metano, amoníaco, água e hidrogénio com um feixe de electrões.

A minha primeira incursão na química pré-biológica, em 1964, quando estava associado a Leslie E. Orgel, no Instituto Salk, foi um estudo desta reacção. Juntamente com Robert Sanchez, encontrámos uma via alternativa para a obtenção de purinas através da fotólise de diaminomaleonitrilo para dar 4-aminoimidazol-5-carbonitrilo. Observámos a conversão deste imidazol e do seu produto de hidrólise, a 4-aminoimidazol-5-carboxamida, numa grande variedade de purinas, incluindo a adenina e a guanina, por reacção com cianeto, cianato e cianogénio.

Mais tarde, no Instituto Politécnico Rensselaer, o meu grupo descobriu que as biomoléculas que Oro tinha observado formarem-se a partir de soluções concentradas de ácido cianidrico podiam também ser produzidas a partir de cianeto 0,01 a $0,1 \mathrm{M}$. Não há a certeza de como é que soluções de $\mathrm{HCN} 0,01$ a $0,1 \mathrm{M}$ se poderiam ter acumulado na Terra primitiva. $\mathrm{O}$ ácido cianidrico é mais volátil do que a água, pelo que uma solução $0,001 \mathrm{M}$ não se teria formado durante a evaporação de um lago primitivo. São plausíveis cenários envolvendo oceanos mais pequenos ou concentrações locais de ácido cianídrico mais elevadas dúvidas a impactos com cometas. 
Talvez a sugestão mais imaginativa tenha sido a de Orgel, que fez notar que a concentração eutética do ácido cianídrico é 74,5 mole $\%$ quando uma solução é arrefecida a $-23,4^{\circ} \mathrm{C}$. Por esta razão, quando uma solução diluída de ácido cianídrico é arrefecida até $-20^{\circ} \mathrm{C}$, a maior parte da água gela, deixando uma solução muito concentrada de ácido cianídrico que reage para dar diaminomaleonitrilo. Contudo, se se conservar a mesma solução à temperatura ambiente, não se detecta oligomerização do ácido cianídrico.

Portanto, a oligomerização do ácido cianidrico pode ter sido iniciada pela congelação de lagos primitivos durante os meses de inverno. Reacções subsequentes dos oligómeros podem ter tido lugar em soluções mais diluídas ou em sedimentos durante os meses mais quentes de verão.

Complementando os esquemas propostos para as purinas, desenvolveram-se também cenários para a síntese pré-biótica das pirimidinas presentes nos ácidos ribonucleicos RNA). Tanto o ácido cianidrico como o cianoacetileno podem ter sido matérias-primas para esta síntese.

O meu grupo de investigação descobriu que, por hidrólise de oligómeros de ácido cianídrico, ao mesmo tempo que se formaram aminoácidos e adenina formavam-se também pirimidinas. A maior quantidade presente era de dihidroxipirimidina, com quantidades mais pequenas de ácido orótico e de 5-hidroxiuracil. Alan Schwartz e os seus colaboradores na Universidade de Nijmegen na Holanda encontraram uracil nos produtos de hidrólise do oligómero de ácido cianídrico.

A formação de compostos representativos das três classes principais de biomonómeros contendo azoto aminoácidos, purinas e pirimidinas - usando ácido cianídrico como a única fonte de carbono é uma descoberta excitante. Todos os três tipos estruturais podem portanto ter sido produzidos ao mesmo tempo e no mesmo lugar na Terra primitiva. Isto não quer dizer que não tivessem existido outras vias para obter estas biomoléculas; provavelmente existiram, especialmente para a formação de aminoácidos. Mas um esquema sintético utilizando a mesma matéria-prima e as mesmas condições reaccionais elimina o problema de sintetisar cada tipo de monómero separadamente, sob condições reaccionais diferentes, e depois reunir os monómeros de modo a poderem dar-se posteriores condensações para a obtenção de polímeros.

\section{Síntese de açúcares}

A ribose é um elemento estrutural essencial na cadeia principal do RNA tal como ele é hoje conhecido. Ela teve provavelmente um papel semelhante nos ácidos nucleicos das primeiras formas de vida na Terra. Apesar das objecções de vulto que iremos mencionar a seguir, o formaldeído parece ser a matéria-prima mais provável para a sintese pré-biótica de açúcares. O formaldeído forma-se facilmente em simulações da Terra primitiva por fotólise de misturas metano-água, monóxido de carbono-água ou dióxido de carbono-água-ferro (II) e por meio de uma descarga eléctrica através de misturas metano-água ou monóxido de carbono-água-azoto.

A condensação de formaldeído ou paraformaldeído para dar uma mistura de açúcares é catalisada por catiōes divalentes, alumina ou argilas em meio ligeiramente alcalino. A reacção dá-se pela condensação sucessiva do formaldeído originando um dímero (glicoaldeído), tri- mero e tetrâmero. O tetrâmero sofre condensação com as unidades mais pequenas dando origem a uma mistura de pentoses, hexoses, heptoses e outros açúcares. É necessária uma concentração inicial de formaldeido superior a $0,01 \mathrm{M}$ para se iniciar este processo de condensação.

Há várias deficiências neste modelo. Em particular, o baixo rendimento em ribose ( 3 a $4 \%$ ) e a formação de uma mistura complexa de açúcares levantam dúvidas acerca da sua validade. A decomposição fácil das aldoses é outro aspecto deficiente neste modelo. A aldose teria que sofrer uma derivatização (talvez originando o nucleósido) logo que se formasse para evitar esta reacção de decomposição.

Como o RNA serviu provavelmente de repositório da informação genética nas formas iniciais da vida em vez do DNA, têm sido estudadas vias pré-bióticas para a sua síntese. Os estudos mais completos sobre a síntese pré-biótica de nucleósidos e nucleótidos têm sido realizados por Orgel, Sanchez, Rolf Lohrmann e seus colaboradores no Instituto Salk. Estes cientistas observaram a formação de nucleósidos púricos por aquecimento de bases heterocíclicas com ribose, por via seca, na presença de iōes divalentes do tipo dos que se encontram na água do mar, como sejam o $\mathrm{Mg}^{2+}$ e o $\mathrm{Ca}^{2+}$. $\mathrm{O}$ aquecimento por via seca é um modelo da evaporação à secura de um lago primitivo seguida do aquecimento subsequente do fundo do lago pelo calor do sol. Os rendimentos de obtenção de uma mistura de anómeros $\alpha$ e $\beta$ dos nucleósidos variam de 2 a $15 \%$ conforme a base púrica usada. Não se formam nucleósidos pirimidicos por este processo.

Foi sugerida uma reacção em fase sólida semelhante para dar conta da formação dos correspondentes nucleótidos. Em 1965, no Centro de Investigação Ames da NASA, Cyril Ponnamperuma e Ruth Mack relataram a formação de nucleótidos por aquecimento de nucleósidos com fosfato inorgânico. Orgel e os seus colaboradores observaram subsequentemente que quando os nucleósidos são aquecidos com ureia e fosfato inorgânico por via seca, os produtos iniciais são derivados contendo grupos $5^{\prime}$-fosfato e $2^{\prime}$ - e 3 '-fosfato. Da continuação do aquecimento da mistura reaccional resulta uma fosforilação adicional, bem como a conversão dos derivados contendo grupos 2 '- e 3 '-fosfato no $2^{\prime}, 3^{\prime}$-diéster cíclico. A adição de $\mathrm{Mg}^{2+}$ à mistura reaccional conduz à formação do $5^{\prime}$-difosfato como produto principal da reacção, havendo rendimentos menores na obtenção do 5 'trifosfato. Este cenário do "lago em evaporação" fornece uma via plausível e simples para a obtenção de nucleótidos tais como a adenosinamonofosfato (AMP), adenosinadifosfato (ADP) e adenosinatrifosfato (ATP), que são algumas das matérias-primas essenciais para a sintese do RNA. Têm sido propostas outras vias para a formação de nucleótidos, envolvendo agentes de condensação pré-bióticos e reacçōes em solução. Compostos como o cianogénio e seus derivados (cianoformamida, cianato e cianamida) não só promovem a fosforilação de nucleósidos, mas originam também a ciclização de nucleósido-2 '- ou 3 '-fosfatos originando o correspondente 2 ', 3 '-fosfato cíclico. Os fosfatos cíclicos são precursores possiveis dos polinucleótidos.

Convertemos recentemente $3^{\prime}$-nucleótidos no $2^{\prime}, 3^{\prime}$ -fosfato cíclico usando dminosuccinonitrilo, um composto formado por oxidação de diaminomaleonitrilo (um tetrâmero do ácido cianídrico) com $\mathrm{Fe}^{3+}$. $\mathrm{O}$ rendimento em fosfato cíclico é aumentado na presença de 


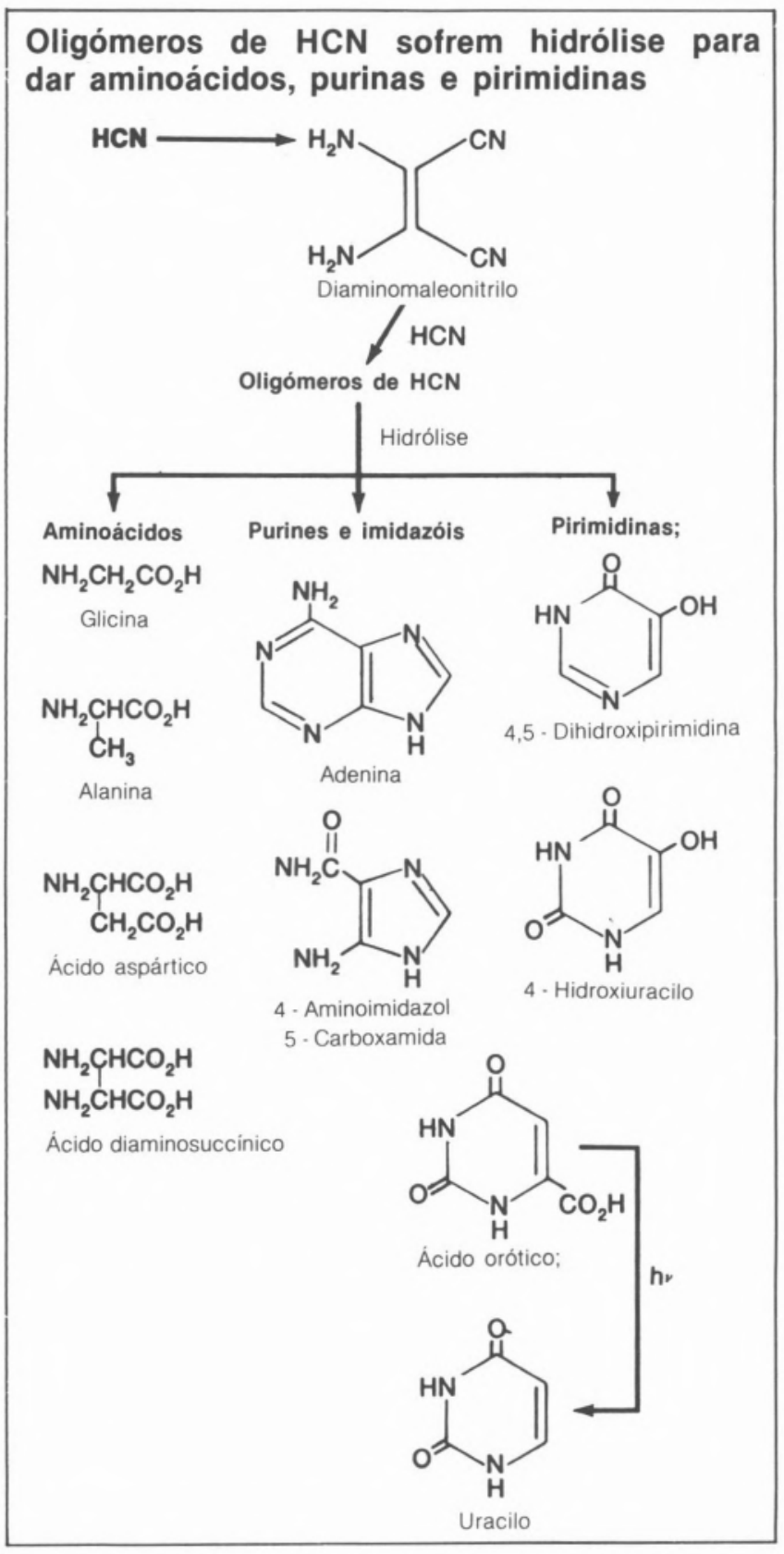

O cenário do lago em evaporação proporciona uma via simplespara a formação de nucleótidos
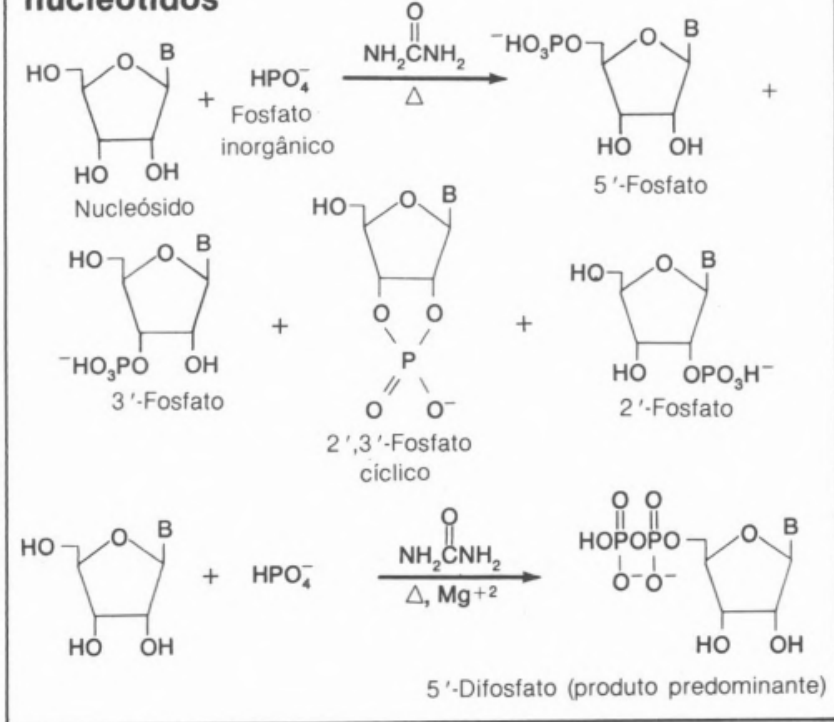

\section{A sintese térmica conduz à formação de péptidos contendo resíduos $\gamma$-glutamilo}<smiles>CCCC(=O)C1CCC(=O)N1</smiles>

Ácido glutâmico

Ácido piroglutâmico

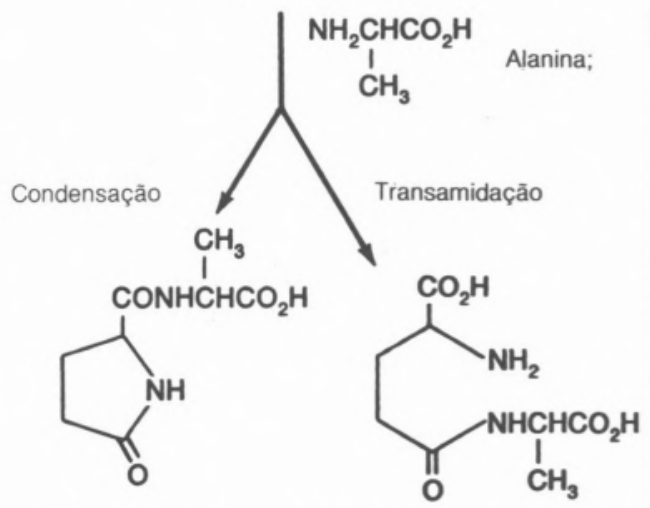

(ligação $\alpha$ ) Co-polimero com $\gamma$-glutamilo (ligação $\gamma$ ).
Os oligonucleótidos formam-se por condensação de $2^{\prime}, 3^{\prime}$-fosfatos cíclicos

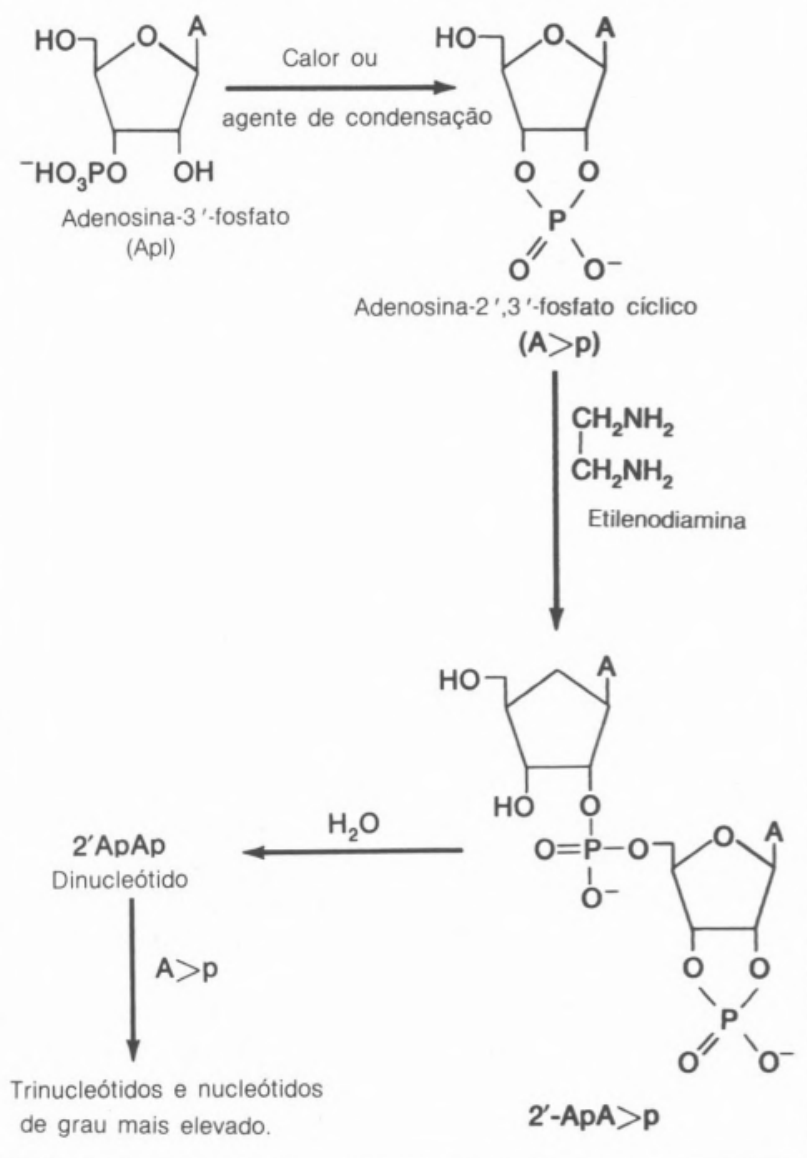


$\mathrm{Mg}^{2+}, \mathrm{Zn}^{2+}, \mathrm{Mn}^{2+}$ e $\mathrm{Pb}^{2+}$. A catálise pelo $\mathrm{Mg}^{2+}$ e $\mathrm{Zn}^{2+}$ tem interesse na medida em que o $\mathrm{Mg}^{2+}$ é um cofactor e o $\mathrm{Zn}^{2+}$ é um componente dos enzimas contemporâneos conhecidos por fosforilases.

Estas reacções sugerem que o cianeto, o cianogénio e os seus derivados, além de terem sido matérias-primas para a sintese de purinas, pirimidinas e aminoácidos, podem ter funcionado como agentes de condensação pré-bióticos. Isto não é de admirar, pois se houve ácido cianidrico suficiente para a síntese das bases heterocíclicas, deve também ter havido uma quantidade suficiente para ser possível o seu envolvimento noutros processos pré-bióticos.

Os lípidos são componentes essenciais das membranas nas células. As membranas são essenciais à vida porque permitem que a célula mantenha um meio reaccional interno bastante diferente do meio externo. As membranas foram importantes para a origem da vida porque a concentração e segregação de certas moléculas orgânicas e inorgânicas devem ter sido um processo importante nas formas de vida mais antigas.

A química pré-biótica dos lipidos não tem sido muito estudada. Um problema importante não resolvido è o da formação de ácidos gordos lineares com mais de 10 átomos de carbono. Estudos recentes feitos em colaboração por George U. Yuen na Universidade do Estado de Arizona e por James G. Lawless e Edward H. Edelson do Centro de Investigação Ames mostraram que se formam praticamente todos os isómeros possiveis dos ácidos monocarboxílicos com dois a sete átomos de carbono a partir de metano, vapor de água, azoto e amoníaco na experiência de Miller de descarga com faísca. Existe uma correlação razoável entre o conjunto de ácidos gordos obtidos pela descarga com faisca e os ácidos gordos isolados a partir de um meteorito carbonoso.

Estudos pelo grupo de Oro e pelo de David Deamer na Universidade da Califórnia, Davis, mostram que se podem formar lípidos mais complexos se se partir de ácidos lineares. Foram obtidos fosfolipidos por condensação de ácidos gordos, fosfato e glicerol por via seca, aquecendo e usando cianamida como agente de condensação. Quando colocados em água, os produtos formam espontaneamente vesículas (membranas de camada dupla), aprisionando estas várias moléculas orgânicas durante a sua formação.

Os coenzimas facilitam um grande conjunto de transferências de grupos e de reacçōes redox nos sistemas bioquímicos contemporâneos. É provável que se tenham formado a partir do conjunto de estruturas orgânicas variadas que predominavam na era pré-biótica, quase como se existisse um artífice molecular que montasse um novo dispositivo a partir de peças disponiveis cada vez que fosse necessário dispôr de um novo catalisador. No entanto, não tem havido muito sucesso na elucidação deste processo de montagem.

\section{Formação de poléplidos}

Imediatamente após ter sido estabelecido que se formavam aminoácidos em experiências de simulação da Terra primitiva, diversos grupos começaram a investigar a via pré-biótica para a formação de polipéptidos. Em experiências de aquecimento por via seca ou de aquecimento de soluções concentradas de aminoácidos obtêm-se produtos oligoméricos contendo algumas ligações peptídicas. Estes estudos simulam a evaporação à secura ou quase secura de lagos com a concomitante concentração dos solutos orgânicos e inorgânicos neles dissolvidos.

Sidney Fox da Universidade de Miami estudou os oligómeros (peso molecular médio igual a 4000) formados por aquecimento por via seca de uma mistura de aminoácidos com um excesso de lisina, ácido glutâmico ou ácido aspártico. Os aminoácidos básicos ou ácidos em excesso inibem a terminação da cadeia polimérica devido à formação de dicetopiperazina.

A presença de aminoácidos multifuncionais tem também como resultado a formação de outras ligações além da ligação peptídica. Por exemplo, quando o ácido glutâmico está presente em excesso, dá-se uma rápida ciclização com formação de ácido piroglutâmico, um composto que só tem um grupo funcional ácido carboxilico e que portanto só pode ocupar a extremidade-N de uma cadeia polipeptídica. Por essa razão, quando se usa uma elevada percentagem de ácido glutâmico, predominam ligações $\gamma$-glutamilo. Para além da presença de ligações não peptíclicas entre aminoácidos, estes polímeros têm uma sequência de aminoácidos resultante de uma distribuição feita essencialmente ao acaso.

Os polipéptidos térmicos de Fox catalisam um certo número de reaç̧ōes relacionadas com as reacções bioquimicas, incluindo a hidrólise do acetato de $p$-nitrofenilo e a descarboxilação do piruvato. Não foi determinado se as propriedades cataliticas observadas são únicas para estes péptidos formados termicamente ou se se pode observar o mesmo efeito catalítico com qualquer polipéptido de sequência arbitrária com uma composição em aminoácidos semelhante. Noam Lahav da Universidade Hebraica de Jerusalém, David H. White da Universidade de Santa Clara e Sherwood Chang do Centro de Investigação Ames investigaram o efeito catalítico de minerais argilosos na sintese de péptidos sob condiçōes pré-bióticas plausiveis. Este grupo observou a sintese de pequenos polipéptidos por aquecimento de aminoácidos à superfície de argilas ricas em caulinite e bentonite e contendo principalmente sódio como catião permutável, tendo usado ciclos alternados de hidratação e desidratação.

A desidratação favorece a formação de péptidos por remoção da água libertada quando se forma uma ligação amídica e por exposição dos aminoácidos a uma superfície ácida de uma argila que catalisa a reacção de condensação. A reidratação conduz à desorpção dos péptidos de superfície, de tal modo que a maior parte dos locais da superfície onde se formaram as ligações peptidicas ficam livres para a acumulação de monómeros e repetição das reacções de condensação no ciclo seguinte. Num estudo relacionado com este, realizado no Centro Ames, Lawless chegou à conclusão que iões $\mathrm{Cu}^{2+}$ associados às argilas aumentavam o rendimento em oligoglicina. Argilas homoiónicas com $\mathrm{Ni}^{2+}$ e $\mathrm{Zn}^{2+}$, preparadas no laboratório a partir da correspondente argila com $\mathrm{Na}^{+}$, revelaram-se também mais efectivas que esta na catálise desta reacção.

\section{Formação de polinucleótidos}

Os polinucleótidos desempenharam um papel fundamental na formação da primeira vida. Eles terão fornecido um mecanismo para preservar a informação bioquímica relativa à primeira forma da vida e terão permitido a possibilidade da sua evolução através de variações nas sequências dos nucleótidos. Por essa razão, o estudo de uma síntese pré-biótica de ribonucleótidos 
plausivel é essencial para a compreensão das origens da vida.

A condensação de $2^{\prime}, 3^{\prime}$-nucleótidos cíclicos foi uma das primeiras vias reaccionais investigadas para a formação pré-biótica de polinucleótidos. Estes $2^{\prime}, 3^{\prime}$ -fosfatos cíclicos formam-se prontamente a partir dos correspondentes 2 '- ou 3 '-fosfatos pelo uso de agentes químicos promotores de condensação ou por aquecimento por via seca. Orgel, Lohrmann e colaboradores no Instituto Salk observaram que a reacção de condensação por via seca é catalisada por diaminas alifáticas, obtendo-se oligómeros que contêm até seis unidades monoméricas. A reacção do adenosina- $2^{\prime}, 3$ '-fosfato ć́clico catalisada pela etilenodiamina dá-se também em fase aquosa na presença de uma matriz polinucleotidica.

A formação de polinucleótidos por condensação de $2^{\prime}, 3^{\prime}$-fosfatos cíclicos é uma via pré-biótica plausível para a obtenção de ribonucleótidos curtos. Esta via é especialmente atraente, uma vez que os 2'- e 3 '-monofosfatos se formam preferencialmente ao isómero $5^{\prime}$ quando os ácidos ribonucleicos sofrem hidrólise. Consequentemente, houve provavelmente uma concentração inicial muito mais elevada das matérias-primas necessárias, $2^{\prime}$ - e $3^{\prime}$-fosfatos, do que de $5^{\prime}$-fosfatos.

Quando o grupo do Instituto Salk publicou pela primeira vez o relato desta sintese, os seus membros expressaram dúvidas que o esquema viesse a ser considerado como uma via pré-biótica provável, porque o oligonucleótido ligado através das posições $2^{\prime}, 5^{\prime}$ predominava sobre o produto natural, que se liga através das posições 3',5'. Mas David A. Usher da Universidade de Cornell fez notar que, embora o isómero ligado através das posições $2^{\prime}, 5^{\prime}$ seja o produto controlado cineticamente, a sua hidrólise é acelerada quando apresenta ligações de hidrogénio numa estrutura de tipo hélice dupla. Usher confirmou esta hipótese experimentalmente e a partir destes dados construiu um cenário para a Terra primitiva em que a maior labilidade da ligação através das posições $2^{\prime}, 5^{\prime}$ terá conduzido ao aumento gradual da quantidade dos polinucleótidos ligados através das posições $3^{\prime}, 5^{\prime}$, que são mais estáveis.

O progresso recente mais dramático na sintese pré-biótica de polinucleótidos foi a obtenção, no Instituto Salk, de oligómeros de 30 a 40 unidades de comprimento, usando como matérias-primas 5 '-fosforimidazólidos. Os 5 '-fosforimidazólidos formam-se, em experiências de simulação pré-biótica, por reacção em fase sólida de nucleosidotrifosfatos com imidazóis à temperatura ambiente num meio com $70 \%$ de humidade.

Por exemplo, o grupo de Salk sintetisou oligómeros do ácido poliguanilico contendo até 40 unidades monoméricas através de reacções do imidazólido do guanosina-5 '-monofosfato (Imp $G$ ) numa matriz de RNA formada por ácido policiticlico [poli(C)], reacções essas catalisadas por iões metálicos. O desenvolvimento de uma técnica de cromatografia de alta eficiência em fase liquida para separação das espécies oligoméricos principais - ambos os isómeros, um ligado através das posições $2^{\prime}, 5^{\prime}$ e outro através das posições $3^{\prime}, 5^{\prime}$, até ao polímero com 40 nucleótidos - foi um factor decisivo para a dedução da via pela qual se dá esta reacção de oligomerização. Tanto o ião $\mathrm{Pb}^{2+}$ como o ião $\mathrm{Zn}^{2+}$ são eficazes na catálise da formação de polímeros com 30 a 40 unidades. No entanto, o efeito do $\mathrm{Zn}^{2+}$ é especialmente notável, porque origina predominantemente liga- ç̃̃es $3^{\prime}, 5^{\prime}$ enquanto que o $\mathrm{Pb}^{2+}$ dá origem principalmente a isómeros $2^{\prime}, 5^{\prime}$.

A especificidade da reacção catalisada pelo $\mathrm{Zn}^{2+}$ é também de realçar. Quando o imidazólido do nucleótido "errado" [um que não forma ligações de hidrogénio de Watson-Crick com a matriz de poli (c)] é misturado com ImpG, o nucleótido errado é incorporado menos de $0,5 \%$ das vezes. Observa-se uma incorporação de $10 \%$ com $\mathrm{Pb}^{2+}$. A fidelidade observada com o $\mathrm{Zn}^{2+}$ difere menos de 10 vezes da observada para as polimerases do RNA.

Estudos recentes pelos químicos do Instituto Salk demonstraram que o 2-metilimidazólido do guanosina-5' -fosfato sofre condensação para dar oligómeros contendo até 50 unidades monoméricas sem necessidade de recorrer a $\mathrm{Zn}^{2+}$ ou $\mathrm{Pb}^{2+}$ como catalisadores. As reacções destes 2-metilimidazólidos são acentuadamente regioespecíficas, com formação quase exclusiva de oligómeros ligados pelas posições $3^{\prime}$ e $5^{\prime}$. A condensação de imidazólidos dirigida por uma matriz, embora sendo apenas um modelo para a replicação pré-biológica dos ácidos nucleicos, constitui um primeiro passo significativo para a compreensão de um processo em que ácidos nucleicos sofram replicação por via não enzimática.

Uma das bases das experiência de Orgel foi a sua convicção que o RNA era essencial para a primeira vida e que não era necessária catálise por proteinas. Orgel sugeriu que as funçðes catalíticas essenciais era asseguradas pelo RNA.

O postulado de que o RNA possuia propriedades catalíticas era contrário ao dogma bioquímico aceite na altura, e era inaceitável, na generalidade, pela comunidade bioquímica. Mas em 1982, Thomas Cech e colaboradores da Universidade de Colorado relataram que o RNA de um protozoário, após sofrer um corte, catalisava a união dos seus próprios fragmentos, facto esse que alterou a regra básica da Bioquímica de que só as proteinas podiam actuar como catalisadores.

Sidney Altman e os seus colegas da Universidade de Yale, trabalhando em colaboração com Worman Pace e os seus colaboradores no Hospital Nacional Judaico em Denver, descobrirem que a actividade catalítica da ribonuclease p é devida a uma molécula de RNA e não a uma proteina, mostraram que a observação feita pelo grupo de Cech não era um exemplo isolado de catálise pelo RNA. Estas descobertas estão de acordo com a proposta de Orgel que o RNA sozinho é tudo o que é necessário para os processos catalíticos da vida primitiva. O RNA pode ter servido de repositório de informação genética bem como de catalisador para as transformações bioquimicas necessárias à célula primitiva.

$\mathrm{O}$ código genético consiste numa série de tripletos de nucleótidos em ácidos nucleicos que especificam a sequência de aminoácidos nas proteínas. Uma característica essencial da vida é a capacidade de armazenar informação (um código genético) e expressar essa informação sob a forma de diferentes proteinas que catalisam processos que ocorrem nas células. Uma das opiniб̌es até agora emitidas é que a primeira vida tinha um código genético bastante impreciso baseado no RNA a partir do qual evoluiu o código contemporâneo. Embora tenham sido feitas muitas propostas inteligentes para explicar a origem deste primeiro código, tem havido uma grande escassez de apoio experimental para qualquer uma delas. Uma excepção é a que postula a origem de um código primitivo como consequência de afinidades selectivas entre aminoácidos e as sequên- 
cias de trinucleótidos dos seus anticóclons (o anticódon é a sequência de trinucleótidos complementar da sequência presente no código para o aminoácido) James C. Lacey Jr. e colaboradores da Universidade de Alabama, Birmingham, usando dados da literatura e resultados de muitas medições feitas por eles próprios, chegaram a uma proposta razoavelmente fundamentada para a existência de uma afinidade selectiva dos aminoácidos pelos nucleótidos dos seus anticódons. Esta correlação não prova que estas afinidades selectivas tenham conduzido à origem do código, mas esta é actualmente a hipótese mais em voga.

Considerando futuras áreas de investigação, não é provável que se detecte vida noutros locais no sistema solar. No entanto, é possível aumentar a compreensão sobre os processos químicos que conduziram às origens da vida. As missões mais promissoras para delinear alguns dos acontecimentos químicos que conduzirem às origens de vida são missões a Titã, a cometas, a asteróides e a Marte.

Uma aterragem poderia determinar se a superfície de Titã, que se encontra à temperatura de $94 \mathrm{~K}$, está ou não coberta por uma lama de hidrocarbonetos e nitrilos formados na atmosfera durante os últimos 4,5 biliōes de anos. Além disso, seria talvez possível chegar a compreender algumas das transformaçōes químicas destes compostos à superfície de Titã. Alguns desses mesmos processos químicos podem ter ocorrido na Terra primitiva. $\mathrm{O}$ aquecimento de uma amostra desta mistura de compostos orgânicos numa grande variedade de condições poderá revelar transformações químicas que tenham tido lugar numa Terra mais quente há 4 biliōes de anos.

Missões enviadas a cometas poderão indicar quais os compostos presentes na núvem de poeiras a partir da qual se formou o nosso sistema solar. Estes compostos podem ter sido transportados para a Terra primitiva por cometas e terem servido como matérias-primas para a evolução química.

Uma missão enviada ao anel asteroidal poderá indicar alguns dos processos químicos que conduziram ao aparecimento de monómeros biológicos na Terra primitiva de uma maneira bastante semelhante àquela em que Titã pode servir de modelo para a formação de olefinas e nitrilos reactivos na atmosfera da Terra. Os asteróides foram propostos como sendo as fontes dos meteoritos carbonosos. Não deve ser difícil trazer amostras para análise, dados os baixos valores de gravidade destes corpos pequenos.

Apesar de não terem sido descobertos sinais de vida antiga como resultado da missão Viking, ainda poderão vir a ser encontradas provas da existência de vida em Marte. A observação de canais de água à sua superficie indica que numa determinada época havia muito mais água superficial e consequentemente uma atmosfera muito mais densa. A evolução química, e talvez mesmo a origem da vida, poderão ter ocorrido nesse ambiente mais hospitaleiro.

Compostos e microfósseis formados de há 3,5 a 4,5 biliōes de anos poderão estar enterrados em sedimentos depositados pelos antigos rios marcianos. A melhor maneira de procurar moléculas orgânicas poderá ser a utilização de uma escavadora capaz de extrair amostras do solo a profundidades abaixo da camada superficial altamente oxidada. As amostras poderiam ser enviadas para a Terra para análise ou então poder-se-ia efectuar a pesquisa de compostos orgânicos nessas amostras em Marte.
Embora tenham sido sintetisados muitos monómeros em estudos de simulação da Terra primitiva, são ainda necessárias experiências convincentes de sintese pré-biótica de Vibose, nucleósidos, ácidos gordos lineares e da maior parte dos coenzimas. Uma tarefa particularmente difícil para os cientistas é sem dúvida a elaboração do projecto de experiências destinadas a mostrar como é que os biopolímeros se formaram a partir destes e doutros monómeros.

Os progressos obtidos na conversão pré-biótica de aminoácidos em polipéptidos têm sido limitados, apesar dos grandes esforços feitos por um certo número de grupos de investigação. Aparentemente, parece ter sido mais fácil sintetisar um RNA de elevado peso molecular e estrutura definida do que um polipéptido de tamanho semelhante. Pequenos polipṕtidos formados pela condensação de aminoácidos ao acaso, poderão ter catalisado a formação de oligonucleótidos maiores na Terra primitiva. Para examinar esta possibilidade são necessárias mais experiências.

Se se admitir que o RNA foi um componente essencial da vida primitiva, há que resolver problemas adicionais acerca da sua sintese. Como é que o grupo fosfato sofreu activação? Terá sido como um imidazólido, como nas experiências de Orgel? Terá sido como o derivado fosforamidado de um aminoácido? Ou terá sido simplesmente como trifosfato, da mesma maneira que nos sistemas bioquímicos contemporâneos? A primeira matriz de RNA terá sido um mineral inorgânico ou argila, um oligonucleótido curto ou uma combinação de ambos? Uma sintese dirigida por uma matriz requer a ligação dos monómeros à matriz, seguida da separação do recém-sintetizado oligómero da matriz. Em geral os oligómeros ligam-se mais fortemente às matrizes do que os monómeros. Como é que se deu então a separação do composto sintetisado? Se se considerar que as afinidades selectivas dos aminoácidos para os nucleótidos do seu anticódon conduziram ao desenvolvimento do código genético, são então necessários estudos experimentais para elucidar como é que estas interacções fracas levaram a um sistema de sintese proteica capaz de sofrer evolução. Forem moléculas simples de RNA contendo estas sequências de anticódons que se ligaram a aminoácidos específicos? Como é que foi feita a selecção dos $\delta$-aminoácidos na presença de $\beta$-aminoácidos, $\delta$ e $\beta$-hidroxiácidos e outros aminoácidos não proteicos no meio pré-biótico? Será que os L-aminoácidos se ligarem mais fortemente aos D-nucleótidos do que os D-aminoácidos? Não é suficiente chegar-se à conclusão que poderá ter sido possível o aparecimento de um código por causa de interacções selectivas aminoácido-nucleótido. O código que vingou teve também como resultado a existência de uma correlação entre as sequências dos ácidos nucleicos e a actividade catalítica dos polipéptidos. A formação de polipéptidos que catalisavam a síntese de oligonucléoticos foi particularmente importante. Uma forma de vida que fosse capaz de catalisar a síntese dos seus próprios ácidos nucleicos teria uma muito maior hipótese de sobrevivência do que uma que dependesse de uma fonte externa, ou de proteina, ou de ácido nucleico.

Estas perguntaś consideram as proteinas e os ácidos nucleicos como a base da primeira vida. É possível arranjar um conjunto semelhante de perguntas, e consequentemente de experiências, para um cenário para a primeira vida do tipo "argilas como precursoras" ou para alguns outros cenários.

No entanto, resta ainda o problema de saber como é 
que esta vida inicial terá sofrido uma segregação do meio ambiente na Terra primitiva. A maior parte dos modelos requer a existência de um recipiente semi-permeável que permitisse a migração selectiva de compostos orgânicos através das suas paredes. Os vesículos de camada dupla formadas a partir de fosfolípidos são até agora os melhores candidatos a esta função. Formam- -se espontaneamente e reparam-se prontamente. Algumas experiências preliminares indicam como é que os aminoácidos se poderão ter difundido através de uma tal membrana. São necessários muito mais estudos para determinar como é que elas surgiram as primeiras células e como é que elas funcionaram num recipiente do tipo de um vesículo formado por lípidos.
O cenário "argilas como precursoras" desafia as opiniões convencionais sobre as origens da vida

A formação de sistemas vivos a partir de moléculas orgânicas na Terra primitiva é o dogma central em estudos das origens da vida. Este ponto de vista tem sido contestado desde há quase 20 anos por A. Graham Cairns-Smith da universidade de Glasgow, Escócia. Segundo ele, nãa haveria concentraçōes suficientemente elevadas de monómeros orgânicos para que estes sofressem condensação espontânea e originassem a formação dos polímeros biológicos essenciais para o primeiro sistema vivo.

De acordo com Cairns-Smith, a primeira vida era constituida principalmente por argilas capazes de sofrerem replicação. Moléculas orgânicas associadas às argilas poderiam ter facilitado a replicação das argilas e outros processos característicos da vida. Estas formas primitivas teriam sofrido evolução por desenvolvimento de estruturas orgânicas mais complexas, até que a maior versatilidade das moléculas orgânicas terá conduzido a um passo na evolução de que teriam resultado formas de vida constituídas quase exclusivamente por moléculas orgânicas.

Cairns-Smith escolheu as argilas como a base da vida primitiva porque as argilas formam-se em grandes quantidades por efeito dos agentes climatéricos sobre as rochas; algumas têm estruturas em camadas típicas dos aluminossiliatos com imperfeições estruturais que possuem propriedades cataliticas. Variações da força iónica ou moléculas orgânicas adsorvidas podem causar um aumento de volume e uma dissociação da argila em camadas separadas, que servem de inóculo para a formação de camadas adicionais da mesma argila. Erros na replicação juntamente com mudanças no ambiente podem ter causado o aparecimento de argilas com velocidades de replicação ou propriedades catalíticas diferentes, conduzindo à evolução de formas de vida diferentes.

O postulado de Cairns-Smith foi reconhecido como uma ideia imaginativa por aqueles que tinham em consideração o papel desempenhado pelas argilas nas origens da vida, mas, atá há pouco tempo, não foi levado muito a sério pela maior parte da comunidade que se interessa pela origem da vida. As suas ideias têm estado agora a atrair a atenção mais a sério como resultado da maior difusão que têm tidos através do seu recente livro "Genetic Takeover" (Cambridge University Press, 1982). O livro foi publicado quase ao mesmo tempo que um artigo da autoria de Armin Weiss da Universidade de Munique [Angew. Chem., Int. Ed. Engl., 20, 850 (1981)] que fornece um suporte experimental ao postulado "argilas como precursoras".

Weiss e os seus colaboradores demonstraram a replicação de argilas com propriedades catalíticas específicas e a retenção dessas propriedades em gerações posteriores da argila. Nas suas experiências, Weiss inoculou uma solução concentrada de silicato de sódio contendo também catiōes aluminio, magnésio e potássio com um cristal de uma argila natural contendo centros catalíticos nos quais a densidade superficial de carga da argila era diferente da que se verificava no resto da argila. A argila com estrutura em camadas formada a partir da argila-mãe foi então usada para inocular soluçōes para formação de outra geração da mesma argila com estrutura em camadas. Este processo foi repetido ao longo de umas 30 gerações e as propriedades de cada geração foram estudadas sob o aspecto de variações da densidade superficial de carga e de propriedades catalíticas da argila de carga e de propriedades cataliticas da argila. Desse modo foi possivel demonstrar a replicação das propriedades catalíticas da argila original até cerca da vigésima geração.

Deve-se salientar que Weiss não realizou estas experiências em condições reaccionais que servissem de modelo às da Terra primitivas. No entanto as experiências são importantes, porque apoiam o postulado de que um sistema inorgânico pode sofrar replicação, de que as gerações seguintes se podem separar da espécie original e de que as argilas-filhas são capazes de conservar as propriedades cataliticas especiais da argila-mãe. 


\section{A origem da assimetria em biomoléculas permanece pouco clara.}

Louis Pasteur foi provavelmente o primeiro químico a investigar as origens da quiralidade que se observa em biomoléculas. $O$ sucesso que obteve na resolução do ácido DL-tartárico por separação dos cristais das formas D e L do tartarato de amónio e sódio levou-o à consideração deste problema. Pasteur propôs que a vida "é uma função da dissimetria do universo"' e que a vida se tornou possivel quando "forças dissimétricas universais" começaram a produzir substâncias quirais.

As forças dissimétricas existentes na Terra, para as quais tem sido postulado terem influenciado a reactividade de moléculas assimétricas, incluem a rotação da Terra num campo magnético, a luz polarizada circularmente e a radiação $\beta$ quiral produzida por decaimento radioactivo.

Os estudos experimentais realizados sobre os efeitos de forças dissimétricas em misturas DL não conduziram ainda a um modelo convincente para a origem da quiralidade. A luz polarizada circularmente deve originar a fotólise preferencial de um dos enantiómeros de uma mistura DL. No entanto, é necessário uma grande destruição pela luz de ambos os enantiómeros para se observar um pequeno excesso de um deles. Além disso, há muita pouca luz polarizada circularmente presente na radiação solar. Estudos semelhantes em que se usaram electrð̄es e positrðes polarizados para destruir selectivamente um enantiómero não conduziram a um enriquecimento enantiómero perceptivel.
A ampliação de um pequeno excesso enantiómero deveria ser um passo essencial para que as forças dissimétricas conduzissem à formação preferencial de um enantiómero. William A. Bonner e colaboradores na Universidade de Stanford observaram um aumento de quiralidade na polimerização de $\mathrm{N}$ -carboxianidridos de aminoácidos em que a quantidade do enantiómero $\mathrm{L}$ estava em excesso. A razão L/D no produto polimérico era superior à do monómero.

Kornel L. Kovacs, do Instituto de Biofísica da Academia Húngara de Ciência, relatou ter verificado a amplificação da polarização da radiação emitida por decaímento $\beta$. A adição de $\mathrm{H}^{3}{ }^{31} \mathrm{PO}_{4}$ a uma solução saturada de tartarato de amónio e sódio - o mesmo composto em que Pasteur observou a formação de cristais separados dos isómeros $\mathrm{D}$ e $\mathrm{L}$ - inicou a cristalização selectiva do enantiómero L. Neste estudo muito completo, realizaram-se mais de 1200 cristalizaç̃es, incluindo 450 cristalizações de controlo sem adição de radioactividade.

Um outro ponto de vista é ter a quiralidade observada em sistemas bioquímicas resultado de um acontecimento fortuito que terá tido lugar imediatamente antes ou pouco depois da origem da vida. Por exemplo, a vida pode ter começado em vários locais da Terra, e os D-aminoácidos podem ter sido utilizados nalgumas formas de vida e os L-aminoácidos noutros. Um acontecimento catastrófico poderia de- pois ter destruido as colónias de microorganismos primitivos baseados em D-aminoácidos ou então a vida baseada nos L-aminoácidos poderia ter adquirido uma vantagem selectiva permitindo-lhe competir mais prontamente por um factor de crescimento ou coenzima específico. Outra alternativa é que a vida $\mathrm{L}$ possa ter conduzido ao desenvolvimento de enzimas capazes de efectuar a destruição dos D-aminoácidos na vida D. É praticamente impossivel examinar experimentalmente as teorias que sugerem ter a quiralidade sido determinada pelo acaso, uma vez que elas são baseadas na premissa de ter havido um acontecimento fortuito.

A conclusão a que chegaram vários participantes num simpósio em 1983 sobre a origem da quiralidade foi que não se percebe ainda como é que a quiralidade se desenvolveu. Alguns exprimiram a opinião de que seria resolvido nos próximos sete anos a questão de se saber se foi um acontecimento fortuito ou se foram forças quirais as responsáveis pela quiralidade observada nos sistemas biológicos. Foi afirmado que, ou haverá alguma revelação nova sobre o papel das forças dissimétricas, ou o problema será abandonado definitivamente por se considerar de resolução experimental impossível. Como a quiralidade na natureza é um tema que tem estado a ser investigado há mais de 100 anos, ficaria muito surpreendido se a sua origem fosse determinada até 1990.

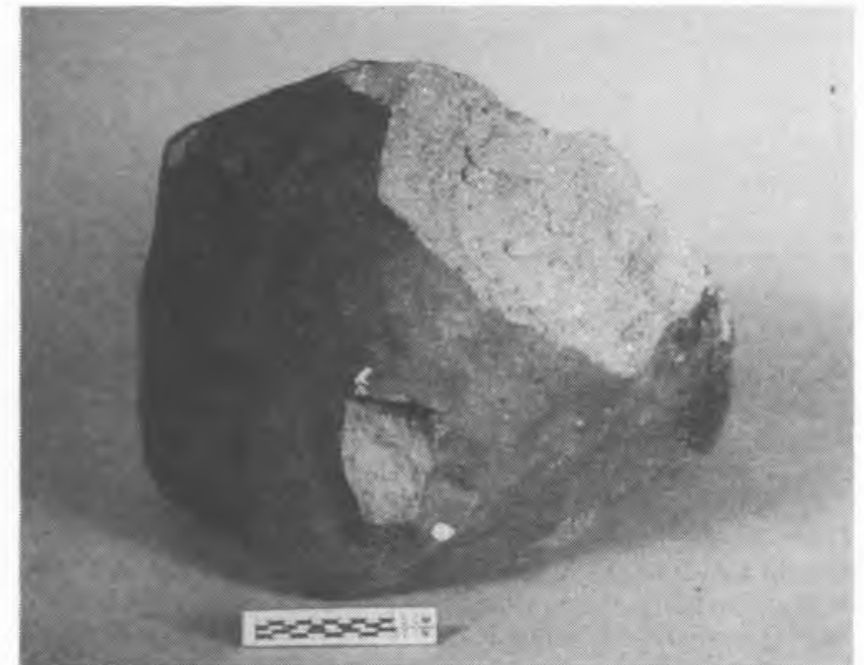

Este meteorito carbonoso, com o peso de $11 \mathrm{~kg}$, caiu em Allende, no norte do México, em Fevereiro de 1969. A parte exterior escura é uma crosta resultante da fusão devida à passagem através da atmosfera. As superficies quebradas mostram o interior, que contém vestigios dos processos mais antigos do sistema solar. Meteoritos semelhantes a este poderão ter trazido para a Terra grandes quantidades de compostos orgânicos pré-formados, durante um periodo de intenso bombardeamento meteoritico verificado de 4,0 a 4,5 biliōes de anos.

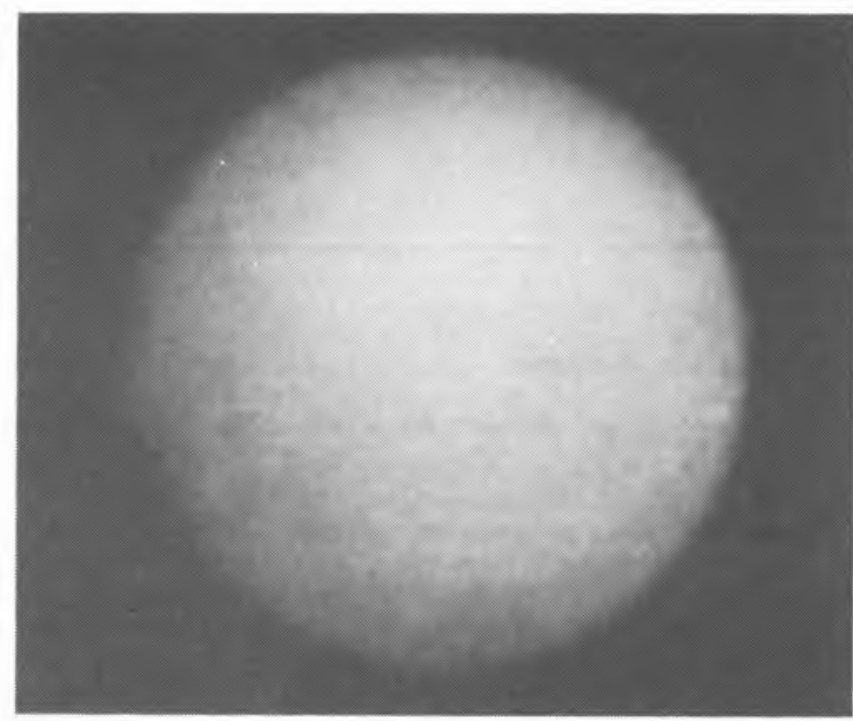

A superfície de Titã, a maior lua de Saturno, está totalmente obscurecida por um aeroso de cor alaranjada constituido por hidrocarbonetos e cianocarbonetos presentes numa atmosfera em que o azoto é o componente predominante. Os processos químicos que originaram este aerosol podem ter sido semelhantes a processos que ocorreram na Terra primitiva. Esta fotografia foi tirada pela nave Voyager 1 em 1980 a uma distância de 12 milhões de $\mathrm{km}$. 

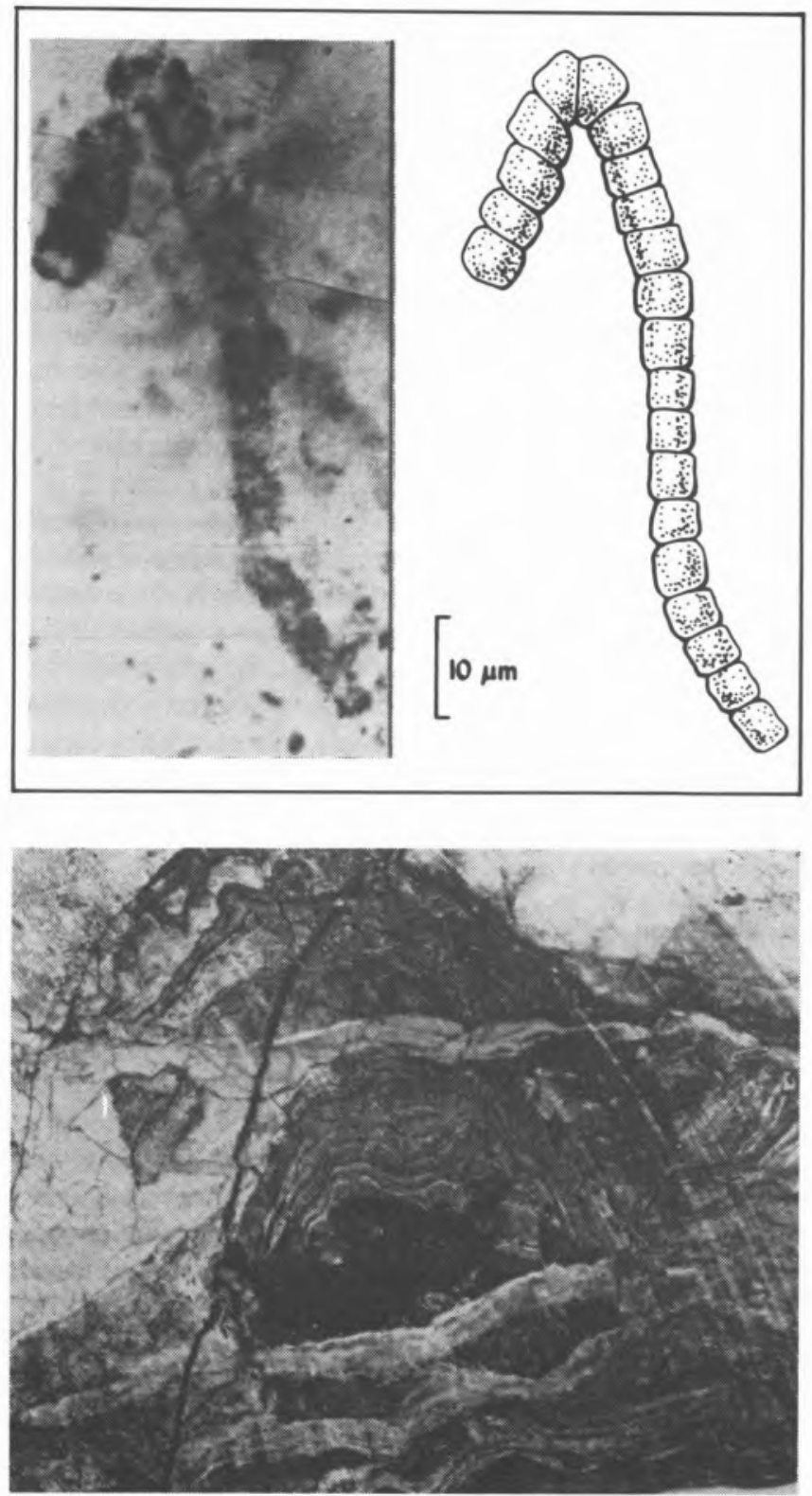

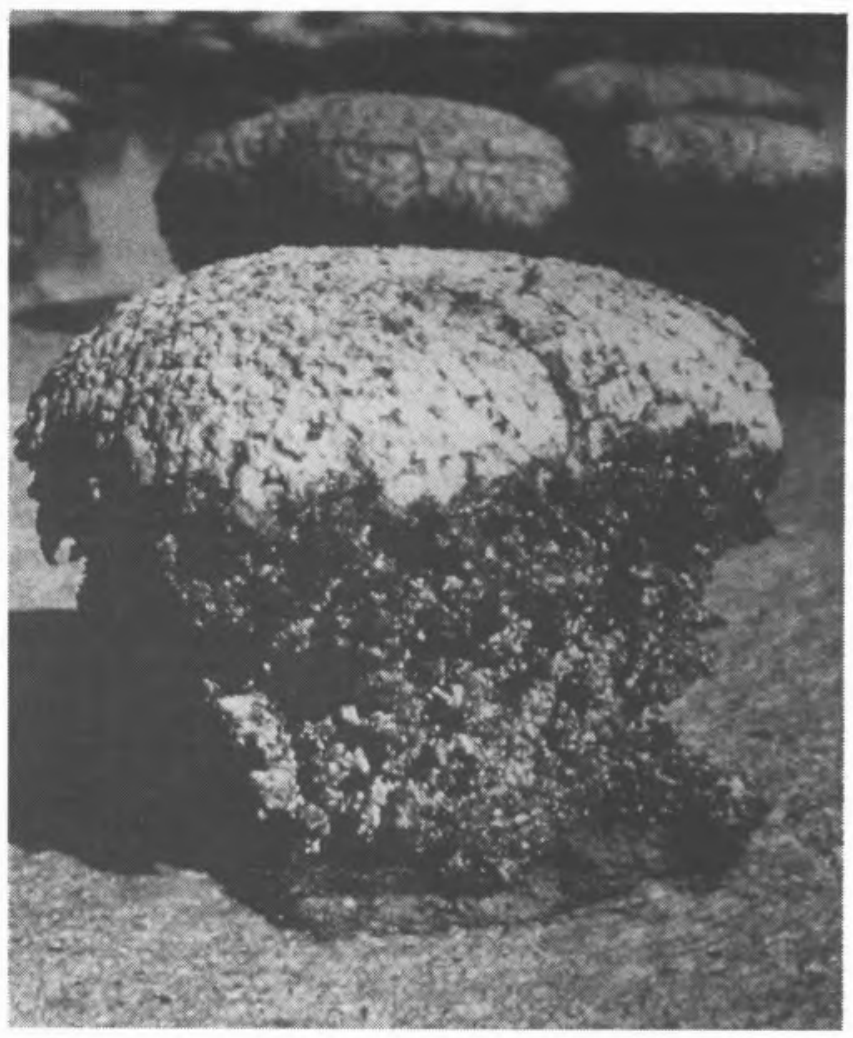

Foi encontrada uma prova da existência de vida microbiana na Terra há 3,5 bilióes de anos em estromatólitos, recifes antigos. Os estromatólitos são estruturas em forma de cúpula que ainda hoje se formam nalgumas bacias de marés de elevada salinidade, como a Baía do Tubarão na Austrália (em cima), como resultado da aderência de areia, calcário e outros pequenos pedaços de rocha às camadas exteriores viscosas de cianobactérias. Cada ano é formada uma nova camada. Um corte de um estromatólito com a idade de 3,5 biliões de anos mostra a estrutura interna laminada parecida com a encontrada em estromatólitos contemporâneos. Uma fotomicrografia mostra um microfóssil filamentoso parecido com uma bactéria (em cima, à esquerda) encontrado no mesmo estromatólito, contendo células com tamanhos de 4 a 7 um. O desenho que a acompanha apresenta uma reconstrução esquemática do aspecto do microfóssil.

\section{Onde é que eles estão?}

“Onde é que eles estão?" foi a questão posta por Enrico Fermi nos anos 40 depois de ter elaborado argumentos plausíveis para a presença de vida inteligente noutros locais da nossa galáxia. A mesma questão continua a pôr-se hoje, após quase 25 anos de uma busca infrutifera para descobrir a existência de inteligência extrarrestre. Se há realmente civilizaçðes extraterrestres em abundância, já devíamos ter detectado alguma prova da sua existência através de sinais de rádio, de sondas robotizadas ou mesmo de viajantes do espaço. Porque é que estes não nos contactaram? O problema da inteligência extraterrestre foi levado a sério pela primeira vez depois da publicação de um artigo em 1959 por Giuseppe Cocconi e Philip Morrison do Instituto de Tecnologia de Massachusetts. Estes autores fizeram notar que, se existissem outras civilizaçðes, era possível que fosemos capazes de detectar os seus sinas de rádio - sinais enviados na nossa direcção ou radiação extraviada das suas comunicações de rádio ou televisão.
Aproximadamente na mesma altura, Frank D. Drake da Universidade de Cornell formulou uma equação, que é agora conhecida por equação de Dra$\mathrm{ke}$, em que fazia uma tentativa de avaliar quantitativamente o número $(\mathrm{N})$ de civilização galácticas capazes de comunicação interestelar. $\mathrm{N}$ é proporcional a vários termos, tais como a origem e evolução da vida, a inteligência e a tecnologia, e também a velocidade de auto-destruição de uma civilização após a sua formação. Obviamente, cada termo tem estado sujeito a um intenso debate, de modo que os valores 
de $\mathbf{N}$ variam entre 1 - a Terra tem a única vida existente na nossa galáxia - e $10^{7}$ a $10^{9}$ civilizaçōes capazes de comunicação interestelar.

Os proponentes da existência de vida extraterrestre em abundância fazem notar que habitamos um planeta que se encontra em órbita em torno de uma estrela bastante típica. Uma vez que há mais de $10^{11}$ estrelas na galáxia, mesmo que a vida tenha surgido em apenas alguns planetas associados a essas estrelas, a vida estaria presente em grande abundância. Muitas dessas estrelas têm uma idade muito superior ao nosso Sol, de modo que devem existir civilizações que têm estado a realizar missões de exploração intergaláctica e de comunicação desde há milhōes de anos e que são muito mais avançadas tecnologicamente do que a nossa civilização.

$\mathrm{Na}$ realidade, alguns proponentes desta teoria partilham do interesse de Fermi em saber porque é que não fomos ainda contactados por esses seres extra-terrestres.

Para tratar deste enigma tem sido proposta a "hipótese do jardim zoológico" tanto na literatura científica como na de ficção científica. Ela sugere que fomos detectados e estamos actualmente a ser observados com a finalidade de ser apreciado como é que se desenvolve a nossa civilização. Os extraterrestres não teriam revelado a sua presença com medo de que a sua tecnologia avançada perturbasse a evolução da nossa cultura e tecnologia, que são únicas.

A razão da ausência de comunicação extra-terrestre pode ser devida ao facto de termos estado a transmitir sinais de rádio desde há pouco tempo, de modo que ainda não chegaram a nenhuma outra civilização. Uma vez detectados estes sinais, faltarão ainda várias centenas de anos até que uma sonda enviada na nossa direcção alcance o nosso sistema solar.

Uma outra hipótese é que os seres extraterrestres poderão ser raros, uma vez que as civilizações evoluem até um certo ponto e depois destroem-se a si mesmas por meio de um holocausto nuclear ou microbiano.

Os que duvidam que a vida extrarrestre seja abundante baseiam os seus argumentos em dois pontos. O primeiro é a questão de Fermi "'Onde é que eles estão?'. O segundo levanta a objecção de que a origem da vida não deve ter sido um acontecimento tão provável como os primeiros cálculos indicaram.
Michael H. Hart da Universidade Trinity em San Antonio fez notar que uma vez que temos hoje a tecnologia necessária para começar a colonização do espaço, muitas gerações de seres vivos oriundas de outros mundos poderiam ter habitado em colónias no espaço à medida que migravam e se estabeleciam na Galáxia. Combustiveis nucleares capazes de fornecer energia podiam ser renovados em qualquer lugar da Galáxia. O processo de exploração, colonização e depois exploração a partir destas novas colónias não é muito diferente da exploração e colonização do Novo Mundo pelos europeus, desde o século XVI até ao século XVIII. Os proponentes desde cenário de colonização crêem que já teria havido tempo suficiente para colonizar a nossa galáxia, porque, de acordo com os cálculos de Eric M. Jones do Laboratório Nacional de Los Alamos, a expansão de uma civilização através de toda a nossa galáxia não levaria mais do que $10^{7}$ a $10^{8}$ anos. Admitindo que levaria aproximadamente o mesmo tempo para que uma civilização avançada nascesse e se desenvolvesse noutro local diferente da Terra $\left(5 \times 10^{9}\right.$ anos), uma onda de colonização a partir de uma civilização tecnológica num planeta que se tivesse formado pouco depois da origem da nossa galáxia (há $10^{10}$ anos) teria atingido o nosso sistema solar pouco depois dele se ter formado (há $4,5 \times 10^{9}$ anos).

Este argumento, envolvendo colonização, é posto em causa por William I. Newman da Universidade da Califórnia, Los Angeles, e Carl Sagan de Cornell, que afirmam que estes cálculos assumem que uma vida mais evoluida tem o mesmo ímpeto para a colonização e exploração que nós temos hoje em dia na Terra. Eles defendem que este ímpeto poderia muito bem diminuir: um aumento da longevidade dos sistemas vivos, devido a uma melhor compreensão dos processos biológicos, levaria a que se atingisse um certo grau de imortalidade. O ritmo de nascimentos numa civilização avançada seria provavelmente controlado de modo a manter um crescimento nulo da população e não haveria vida inteligente suficiente para popular a galáxia.

Em resposta a estes argumentos, Jones afirma que a sua teoria necessita apenas que o crescimento da população seja maior que zero junto à fronteira da colonização e considera a existência de um crescimento nulo em todos os outros locais. Se se considerar a colonização europeia das Américas como uma anologia válida, então existiria uma maior população de aventureiros junto às fronteiras, população essa que continuaria a expandir-se para além delas.

Hart crê também que a existência de vida extrarrestre é improvável. Os seus cálculos sugerem que a sua vida teve a sua origem na Terra apenas porque existiu um conjunto muito especial de condiçōes nos últimos $4,5 \times 10^{9}$ anos, condições essas que existiram apenas até certo ponto, noutros locais da Galáxia. Hart chega a esta conclusão por formulação de um modelo matemático da atmosfera primitiva da Terra e por cálculo da evolução dessa atmosfera ao longo do tempo geológico, concluindo que a Terra está situada numa zona estreita temperada em volta do sol onde é possivel a existência de vida.

No entanto, Tobias C. Owen e Robert D. Cess da Universidade do Estado de Nova Iorque, Stony Brook, e Veerabhadran Pamanathan do Centro Nacional para a Investigação Atmosférica, Boulder, Colorado, fazem notar que a extensão desta zona habitável depende muito da composição atmosférica que se considerar para o planeta. Os gases atmosféricos que absorvem na região infravermelha do espectro impedem que o calor se escape pelo efeito de estufa.

O aparecimento de provas da existência de vida extraterrestre evitaria a necessidade destes debates especulativos. Embora se tenham já realizado cerca de 15 programas de pesquisa de sinais espaciais, apenas se inspeccionou ainda uma pequena fracção do céu. $O$ apotegma que Sagan usa neste debate é ainda válido: "A ausência de prova não é necessariamente uma prova da ausência".

A detecção de comunicações intragalácticas seria certamente uma descoberta com um significado científico e filosófico tão grande que merece continuar a ser apoiada. Os progressos em computação tornam possível uma cobertura mais completa numa gama de frequências mais larga do que a que tem sido possível efectuar até agora. Por exemplo, podia-se realizar uma inspecção de todo o céu na região das microondas do espectro electromagético em cinco anos, utilizando equipamento actualmente disponivel. A ausência de provas, após um estudo completo, tornar-se-ia então significativa. 


\begin{tabular}{|c|c|c|c|}
\hline Espaço interestelar & Cometas & Titã & Meteoritos carbonosos \\
\hline \multicolumn{4}{|l|}{ Hidrocarbonetos } \\
\hline $\begin{array}{l}\mathrm{CH}_{1} \mathrm{CH}^{+}, \mathrm{CH}_{4}, \mathrm{HC}_{2}, \mathrm{HC}_{2} \mathrm{H}, \\
\mathrm{HC}_{2} \mathrm{CH}_{3}\end{array}$ & $\begin{array}{l}\mathrm{C}, \mathrm{C}^{+}, \mathrm{CH}, \mathrm{CH}^{+}, \mathrm{C}_{2} \\
\mathrm{C}_{3}\end{array}$ & $\begin{array}{c}\mathrm{CH}_{4}, \mathrm{C}_{2} \mathrm{H}_{6}, \mathrm{C}_{3} \mathrm{H}_{3}, \mathrm{C}_{2} \mathrm{H}_{4}, \mathrm{C}_{2} \mathrm{H}_{2}, \\
\mathrm{H}-\mathrm{CC}-\mathrm{CH}, \mathrm{CH}_{3} \mathrm{C}=\mathrm{CH}\end{array}$ & $\begin{array}{l}\text { Compostos alifáticos, aliciclicos } \\
\text { e aromáticos } \mathrm{C}_{1} \text { a } \mathrm{C}_{20}\end{array}$ \\
\hline \multicolumn{4}{|l|}{ Álcoois } \\
\hline $\mathrm{OH}, \mathrm{H}_{2} \mathrm{O}, \mathrm{CH}_{3} \mathrm{OH}, \mathrm{C}_{2} \mathrm{H}_{5} \mathrm{OH}$ & $\begin{array}{l}\mathrm{O}, \mathrm{OH}_{2} \mathrm{OH}^{+} \\
\mathrm{OH}^{+}, \mathrm{H}_{2} \mathrm{O} \text {. }\end{array}$ & & $\mathrm{H}_{2} \mathrm{O}$, Álcoois C, a C, \\
\hline \multicolumn{4}{|l|}{ Aldeidos e cetonas } \\
\hline $\mathrm{HCO}, \mathrm{HCO}^{+}, \mathrm{H}_{2} \mathrm{CO}, \mathrm{CH}_{3} \mathrm{CHO}$ & $\mathrm{C}, \mathrm{CO}, \mathrm{CO}^{*}, \mathrm{HCO}$ & & $\begin{array}{l}\text { Aldeidos e cetonas } \mathrm{C}_{2} \text { a } \mathrm{C}_{5} \\
\qquad \mathrm{H}_{2} \mathrm{CO}\end{array}$ \\
\hline \multicolumn{4}{|l|}{ Ácidos e seus derivados } \\
\hline $\begin{array}{l}\mathrm{CO}, \mathrm{C}_{3} \mathrm{O}, \mathrm{CH}_{2}-\mathrm{C}-\mathrm{O}, \mathrm{HCO}_{2} \mathrm{H}, \\
\mathrm{HCO}_{2} \mathrm{CH}_{3}\end{array}$ & $\mathrm{C}, \mathrm{O}, \mathrm{CO}^{+}, \mathrm{CO}_{2}^{+}$ & $\mathrm{CO}, \mathrm{CO}_{2}$ & $\begin{array}{l}\mathrm{CO}_{3}^{+} \mathrm{CO}_{2}, \mathrm{CO} \text {, ácidos mono- } \\
\text { e dicarboxilicos } \mathrm{C}_{2} \text { a } \mathrm{C}_{8}\end{array}$ \\
\hline \multicolumn{4}{|l|}{ Aminas e seus derivados } \\
\hline $\begin{array}{l}\mathrm{NH}_{3}, \mathrm{CH}_{2} \mathrm{NH}, \mathrm{CH}_{3} \mathrm{NH}_{2}, \mathrm{NH}_{2} \mathrm{CHO}, \\
\mathrm{NH}_{2} \mathrm{CN}, \mathrm{HNCO}\end{array}$ & $\begin{array}{l}\mathrm{NH}, \mathrm{NH}^{+}, \mathrm{NH}_{2}, \mathrm{NH}_{3} \text {, } \\
\mathrm{N}_{2}^{+}\end{array}$ & $\mathrm{N}_{2}$ & $\begin{array}{l}\text { Aminoácidos, aminas } \mathrm{C}, \text { a } \mathrm{C}_{\boldsymbol{*}} \\
\mathrm{NH}_{3}, \mathrm{~N} \text {-heterociclos }\end{array}$ \\
\hline \multicolumn{4}{|l|}{ Nitrilo } \\
\hline $\begin{array}{l}\mathrm{CN}, \mathrm{HCN}, \mathrm{HNC}, \mathrm{NH}_{2} \mathrm{CN}, \mathrm{C}_{2} \mathrm{CN}, \\
\mathrm{CH}_{2}=\mathrm{CHCN}, \mathrm{CH}_{3} \mathrm{CN}, \\
\mathrm{CH}_{3}=\mathrm{CCN}, \mathrm{C}_{2} \mathrm{H}_{5} \mathrm{CN}, \\
\mathrm{H}\left(\mathrm{C}=\mathrm{C}_{h} \mathrm{CN} \mathrm{n}=1-5\right)\end{array}$ & $\mathrm{CN}, \mathrm{CN}^{*}, \mathrm{HCN}, \mathrm{CH}_{3} \mathrm{CN}$ & $\begin{array}{l}\mathrm{HCN}, \mathrm{HC}=\mathrm{CCN}, \\
(\mathrm{CN})_{2}\end{array}$ & \\
\hline \multicolumn{4}{|l|}{ Outras espécies... } \\
\hline $\begin{array}{l}\mathrm{H}_{2} \mathrm{H}_{2} \mathrm{CS}, \mathrm{CS}, \mathrm{SO}, \mathrm{OCS}, \mathrm{H}_{2} \mathrm{~S} \\
\mathrm{SO}_{2}, \mathrm{NS}, \mathrm{SiO}, \mathrm{N}_{2} \mathrm{H}^{+} \\
\mathrm{CH}_{3} \mathrm{OCH}_{3}\end{array}$ & $\underset{\text { metais }}{\mathrm{H}, \mathrm{CS}, \mathrm{S}, \mathrm{S}_{2}, \mathrm{H}_{2} \mathrm{~S}^{+} \text {, }}$ & $\mathrm{H}_{2}$ & O- e S. heterociclos \\
\hline
\end{tabular}

Fonte: Adaptado de Sherwood Chang em "Space Mission to Comets”, NASA conference Publication, 2089, 1977, p. 74.

\section{BIBLIOGRAFIA SELECCIONADA}

Livros

Day, W., "Genesis on Planet Earth", 2nd Ed., Yale University Press, New Haven, Conn., 1984.

Miller, S. L., Orgel, L. E., "The Origins of Life on the Earth", Prentice-Hall, Englewood ZCliffs, N. J., 1974.

Ponnamperuma, C. (Editor), "Comets and the Origins of Life", Reidel, Dordrecht, the Netherlands, 1981.

Schopf, J. W. (Editor), "Earth's Earliest Biosphere. Its Origin and Evolution", Princeton University Press, Princeton, N. J., 1983.

Walker, J. C. G., "Evolution of the Atmosphere", Macmillan, New York, 1977.
Resenhas criticas

Eigen, M., Gardiner, W., Schuster, P., Winkler-Oswatitsch, R., "The Origin of Genetic Information", Scientific American, 244(4), 88 (1981).

Ferris, J. P., Hagan, W. J., Jt., "HCN and Chemical Evolution. The Possible Role of Cyano Compounds in Prebiotic Synthesis", Tetrahedron, 40, 1093 (1984).

Ferris, J. P., Usher, D., "Origins of Life" in "Biochemistry" (G. Zubay, Editor), Addison-Wesley, Boston, 1983, p. 1190.

Greenberg, J. M., "The Structure and Evolution of Interstellar Grains”, Scoentific American, 250(6), 124 (1984).

Lacey, J. C., Jr., Mullins, D. W., Jr., "Experimental Studies Related to the Origins of the Genetic Code and the Process pf Protein Synthesis - A Review", Origins of Life, 13, 3 (1983).

Owen, T., "Titan", Scientific American, 246 (2), 98(1982).

\section{COLABORE COM A SOCIEDADE}

\section{NÃO ATRASE O PAGAMENTO DAS SUAS QUOTAS}

